\title{
Independence and Family Support as the Cost and Reward Influences the Women's Marriage Decision: A Cross-sectional Study
}

\author{
Jeeja Hernole ${ }^{1}$ and Abhishek Dhawan ${ }^{2 *}$ \\ ${ }^{1}$ Research Scholar, Department of Biotechnology, Visvesvaraya Technological University, India \\ ${ }^{2}$ Consultant Scientist, Research Department Agricultural Development Trust, Baramati, India \\ *Corresponding author: abhishek27099@gmail.com (ORCID ID: 0000-0001-5586-7486)
}

Received: 23-10-2020

Revised: 22-01-2021

Accepted: 25-02-2021

\begin{abstract}
Marriage is an important event in an individual's life. The decision of choosing the right partner is partially based on the human survival instinct that psychologically orients with cost vs reward assessment strategy. Hence, to identify the factors that influence a woman when she selects the right alliance for marriage, a survey-based statistical analysis study was performed by $n=107$ women who participated. In this study, it is observed that the current family type influences the women's preference for partners' family type post marriage. Age also plays an important role when women make considerations for post-marriage family type. Moreover, women evaluate and consider situations such as independence, family support as the cost/reward categories to make choices when it comes to family type post marriage. In addition to this, women highly prefer tier 1 over the tier 2 cities as well as the future husband having a job or business but the least preference is given to an individual with the farming occupation. Therefore a noticeable shift in the trend of cost vs. reward assessment in matrimonial selection is seen. Moreover, the inclination towards nuclear family type is increasing compared to a joint family which may have on the Indian socio-economic scenario.
\end{abstract}

\section{Highlights}

(0 Indian women are opting for nuclear families as compared joint families.

0 Initially presumed rewards by women for marital cohabitation such as family support, discipline, bonding are strategically shifted into the cost category from reward category.

(0 Age, Education and choice for independence resultantly impacts in an increase in inclination towards the nuclear family.

Keywords: Cost vs. reward, Indian matrimony, marriage trends, joint family, nuclear family

Human survival instinct to a certain extent is aligned neurobiologically with cost $\mathrm{v} / \mathrm{s}$ reward assessment strategy. Multiple neural pathways are assessed to decide which liable cost to be incurred for a certain choice by humans (Rudebeck et al. 2006). The choices and decisions that one makes are based on different personal priorities, pre-acquired knowledge (Dhawan et al. 2020), and individual risk assessment (McGloin et al. 2016). One of the most primary decisions one makes in the Indian cultural setting is about their marriage. Many socio-cultural aspects play an important role

How to cite this article: Hernole, J. and Dhawan, A. (2021). Independence and Family Support as the Cost and Reward Influences the Women's Marriage Decision: A Cross-sectional Study. Int. J. Soc. Sci., 10(01): 15-19.

Source of Support: None; Conflict of Interest: None (क) 9 
in an individual's partner choice. Love and arranged marriages are both prevalent in Indian social structure but there is a rise in love marriages viz. individuals choosing their partners on their own rather than the dominant influence of families that was followed in patriarchal days (Gupta et al. 1976; Black et al. 2017)). One of the most prominent considerations for women when it comes to choosing their partner is the type of family concerning family size and its structure (Bhandari et al. 2018), locality of living and partner's profession. In India, the joint familial structure is declining with rising nuclear familial structures. Currently, due to a shift in work culture, there is a further division happening in nuclear families with parents and children living indifferent places (Kolenda et al. 1968). In Indian culture, brides cohabit with the groom at the groom's place after marriage. Each individual assesses some cost and rewards before making any decision may it be their marriage (Gopalkrishnan et al. 2007). This cross-sectional study aimed to find what influence family structure has on a woman's choice for her husband. Also, what the costs-reward shifts psychologically happening in the current generation vs older generation concerning husband selection. In this study, we analyzed the choices of $n=107$ women of age ranging from 18 to 42 years for their expected family type, location and profession post marriage.

\section{Methodology}

The study was based on a survey analysis method (Hayes et al. 1998). The questionnaire was made using Google forms and circulated amongst the different groups for getting the responses from women of different ages and marital status. The written consent and approval was taken from the participants at the beginning of the survey study form as per relevant guidelines and regulations. The research was survey-based and does not involve experiments on humans or human tissue. The total number of responses for the study received was $n=107$ after error correction, removal of ambiguity and incorrect responses. Mean age $=28$ years mode $=26$ years and age deviation $\sigma=5.476$ Out of which married were $n=61$ and unmarried were $n=46$. The survey form questionnaire is as given in the supplemental file. The main aim of the questionnaire was to extract specific information relevant to the research focus and make analysis and find the interlinked factors that make the effect on groom choices such as type of family preferred, Expected Living preference, Factors supporting the choices, etc. The data was collected in an excel sheet for analysis using statistical methods.

\section{OBSERVATION AND RESULTS}

\section{Current Family type primes the preference of the future family type}

The study was intended to analyse the factors that changed the trends of women's preference from the previous family (nuclear/joint) type to expected family type (nuclear/joint).

Out of $n=107$ (Graph 1), women $(n=49)$ who believed that living with husband and in-laws together is beneficial, $87.7 \%(n=43)$ of those chose to live with husband and in-laws and $13.3 \%(n=6)$ of those chose to live with a husband in different house and in-laws at distant future. On the contrary, women who thought living with a husband in a different house and in-laws at a distant is beneficial $(n=58), 100 \%(n=58)$ choose to live with a husband in a different house and in-laws at a distant. This stipulates that the percentage of women who believe nuclear families beneficial do not entirely prefer joint family type. But, women who believe joint family type beneficial may prefer the nuclear family type in future (Graph 1). The current family type primes the maximum women in the selection of future family type Also this is an acceptable psychological response since an individual is comfortable with a previously experienced family type invariant of other factors.

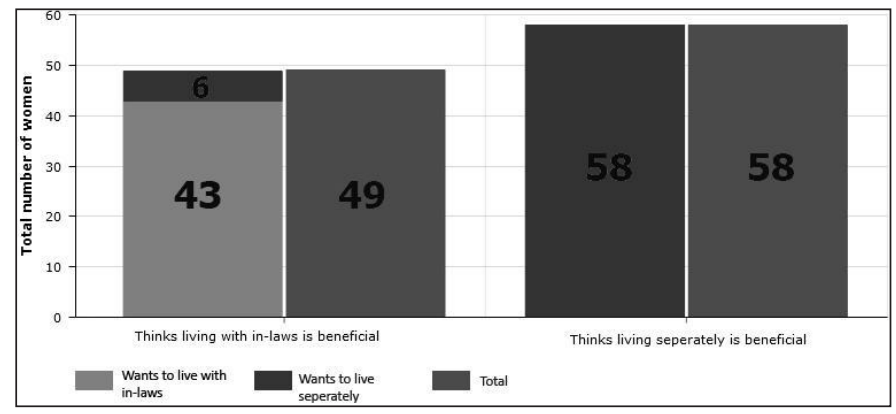

Graph 1: Current family type vs Preferred Family type post marriage 
Preference of Independence, as a reward and Familial support as cost, influences the women to see fit their family choice post marriage

To primarily identify the reasons that make women prefer a particular family type post marriage, we analysed and inferred based on the reasons the women as subjects selected for two questions: "What are the benefits you think of living separately with the husband at a different place?" and "What are the benefits you think of living with in-laws?" Women who opted for nuclear families post-marriage $(n=64)$ (Table 1$), 81 \%(n$ $=52$ ) of those chose 'independence' as a major factor for their preference. On the contrary, the women who chose joint families $(n=43), 93 \%(n=40)$ of those chose 'Family support' as a major factor for their preference (Table 1). Based on the above trends, in an Indian cultural setting, the women who prefer the nuclear family type distinguish "independence" as a reward over "familial support" as a cost, to make a decision and the other way around.

Table 1: Independence in Nuclear and Family support in Joint

\begin{tabular}{lll}
\hline $\begin{array}{l}\text { Preferred family type vs Benefits of } \\
\text { Nuclear I Benefits of Joint }\end{array}$ & Joint (43) & $\begin{array}{l}\text { Nuclear } \\
(64)\end{array}$ \\
\hline Who selected Independence (77) & $58 \%(25)$ & $81 \%(52)$ \\
\hline Family Support (77) & $93 \%(40)$ & $58 \%(37)$ \\
\hline
\end{tabular}

\section{Age influences the women to choose their family type post marriage}

One of the prominent observations in this study leads to mark the effect of age on family type preference post marriage. In the age group (Graph 2) of 18-26 years $n=$ $51,45 \%(n=23)$ of those preferred joint family and $55 \%$ $(n=28)$ preferred nuclear, in age group 27-34 age group $(n=36), 39 \%(n=14)$ of those preferred joint family and $55 \%$ preferred nuclear and in 35-42 age group $(n=20)$, $30 \%(n=6)$ of those preferred joint family and $70 \%(n=$ 14) preferred nuclear. Therefore, it could be subjectively inferred that with the increasing age, women tend to find it preferable to live in nuclear families as compared to joint families.

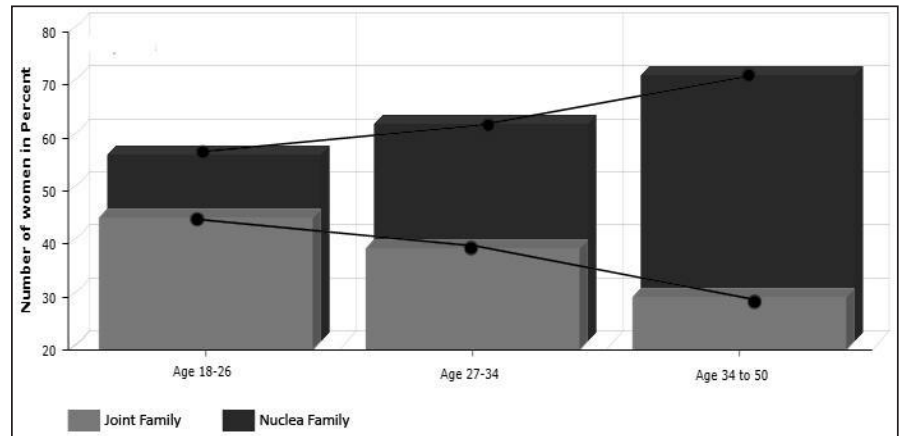

Graph 2: Effect of age (generation) on the preferred family type

Women's preference of location and husband's profession post-marriage may influence youth to migrate towards cities and less engage in farming
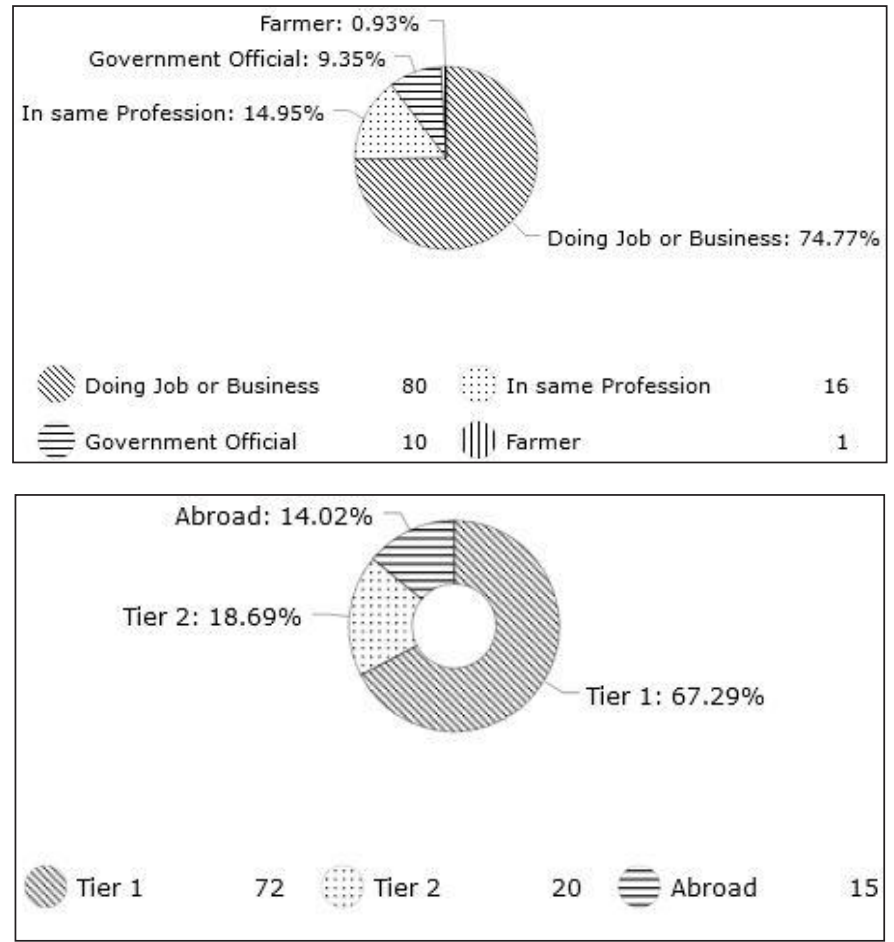

Graph 3: Women preference for the type of locality and husband profession post marriage

One of the most important aspects in the decision of family type post marriage in the current generation is influenced by the place of living and husband's profession post marriage. From the study responses (Graph 3) $n=$ $72(67.69 \%)$ preferred Tier 1 or metropolitan cities, $n=$ $20(18.69 \%)$ preferred Tier 2 cities or villages, and $n=15$ 
(14.02\%) preferred to stay abroad post marriage. Only $1(0.93 \%)$ woman preferred her husband to be a farmer. Most of the women i.e. $74.77 \%$ preferred a husband who is either doing a job or having a business. It could be presumed that there is a drastic shift in choice-making as 70 per cent of rural households still depend primarily on agriculture for their livelihood (www.fao.org) but still there is very less preference given by the women for a farmer. India is a village driven country with almost $68.84 \%$ of the Indian population (censusindia. gov.in) living in villages or tier 2 . It is observed that the women have a major inclination to prefer tier 1 cities post-marriage (Graph 3), this can subject to subsidiary migrative effects.

\section{DISCUSSION}

In the patriarchal society of India, the Joint family could be defined as a family comprising more than three members of two or three generations descending from a man and a woman (Madan, 1962). Although these definitions are very old, in urban India, nowadays, the joint families comprise in-laws, husband-wife and their children while nuclear families have husband-wife and children, and in-laws may be living distant in different households. This cross-sectional study was designed to assess pre and post-marital family structure selection and its cost $\mathrm{v} / \mathrm{s}$ reward assessment. It is observed that inclination towards the joint family setting is declining considerably. Women are opting for nuclear families by more than $59 \%$ as compared to women preferring joint families. Although initially thought and perceived rewards by women post marriage such as support from the family in different circumstances, the help of inlaws in raising kids, etc is overridden by the rewards such as independence, less interference of members of the family in the current generation. In this study, we observed that there is a paradigmatic shift in cost and reward assessment calculation as compared to the older generation. Initially presumed rewards by women for marital cohabitation such as family support, discipline, bonding are strategically shifted into the cost category from reward category. The women's preference for tier 1 cities is growing exponentially as compared to earlier decades. $82.076 \%$ of the population in 1960 was living in villages that have been curbed down to $65.528 \%$ in 2017 (data.worldbank.org), The change in preference of women towards tier 1 cities post-marriage may add up to curbing this village population as more young men may tend to move towards cities (Singh et al. 2020). Also, women are opting for men doing jobs or business more with the least choice for farmers. This could further lead to youth less engaging in farming activities and other farming consequences. This is also affecting the current matrimonial situation in rural India as still most of the families in rural India are joint and agriculture-based. The choice for nuclear families in modern-day India can be due to economic shift, dual-income need and individual preference reasons (Luke et al. 2011). The old patriarchal behaviour, dominance of in-laws, and low liberal status, prominently results in a shift of presumed costs and rewards. (Sannen et al. 2003). In addition to this, we observed that, with the growing age of married women and children, the women's need for child support from in-laws decreases. Also, the girl child is raised educated and made economically independent. Both factors resultantly impact an increase in inclination towards the nuclear family.

\section{REFERENCES}

Bhandari, P. 2018. Makings of Modern Marriage: Choice, Family, and the Matchmakers. In Exploring Indian Modernities (pp. 131-149). Springer, Singapore.

Black, S. 2017. Love marriage. South Asia: J. South Asian Stu., 40(2): 345-348.

Date accessed: 19 ${ }^{\text {th }}$ January, 2021 https://censusindia.gov.in/2011common/censusdata2011.html

Date accessed: 19th January, 2021 https://data.worldbank.org/ indicator/SP.RUR.TOTL.ZS?locations=IN

Dhawan, A. Role and Priming Effect of Pre-Acquired Memories in Abstract Decision-Making. Available at SSRN 3688249.

Date accessed: 19th January, 2021 http://www.fao.org/india/faoin-india/india-at-a-glance/en/

Gopalkrishnan, N. and Babacan, H. 2007. Ties that bind: Marriage and partner choice in the Indian community in Australia in a transnational context. Identities: Global Studies in Culture and Power, 14(4): 507-526.

Gupta, G.R. 1976. Love, arranged marriage, and the Indian social structure. J. Comparative Family Stu., 7(1): 75-85. 
Hayes, B.E. and Hayes, B.E. 1998. Measuring customer satisfaction: Survey design, use, and statistical analysis methods. Milwaukee eWisconsin Wisconsin: ASQC Quality Press.

Kolenda, P.M., Singer, M. and Cohn, B.S. 1968. Region, caste and family structure: a comparative study.

Luke, N. and Munshi, K. 2011. Women as agents of change: Female income and mobility in India. J. Dev. Econ., 94(1): 1-17.

McGloin, J.M. and Thomas, K.J. 2016. Incentives for collective deviance: Group size and changes in perceived risk, cost, and reward. Criminology, 54(3): 459-486.
Rudebeck, P.H., Walton, M.E., Smyth, A.N., Bannerman, D.M., and Rushworth, M.F. 2006. Separate neural pathways process different decision costs. Nature Neuroscience, 9(9): 1161-1168.

Sannen, A., Van Elsacker, L., Eens, M., Heistermann, M. and Möhle, U. 2003. Urinary testosterone metabolite levels in bonobos: a comparison with chimpanzees in relation to the social system. Behaviour, 140(5): 683-696.

Singh, R. 2020. Cultural and Social Impediments for Girls in Pursuing Higher Education in Rural India. Available at SSRN 3642664. 
